\title{
Gender Disparity in Second Language Learning: Reality or Illusion?
}

\author{
Syed Md Golam Faruk \\ Directorate of Secondary and Higher Education, Chittagong, Bangladesh \\ Rajib Saha \\ Chittagong City Corporation Premier College, Chittagong, Bangladesh
}

\begin{abstract}
The paper draws a comparison between female and male students' language learning capabilities in the backdrop of age-old idea that males are better than females in language learning on the one hand, and some recent study findings indicating females' superiority over males on the other. To this end, 43 female and 80 male higher secondary students' 468 answer scripts of their regular English exams were collected. For the traditional question pattern, the collected data could measure only "remembering" and "understanding" of the examinees. Therefore, the students were compared only on the basis of these two lowest levels of Bloom's taxonomy. The participants were of same age, studying at the same level (Grade 11), and were taught by the same teacher. The study finds that if other variables remain the same, there is no essential difference between male and female regarding learning English as a second language.
\end{abstract}

Keywords: female students, male students, learning English as a second language, Bloom's taxonomy, Bangladesh

\section{Introduction}

Since the formation of patriarchal societies, man has always been considered to be superior to woman in almost all aspects of life including language learning. Although no study had been conducted in order to measure the difference between the sexes in terms of linguistic ability, men clearly established, at least until the19th century, the fact that they were superior to women in oration, writing, and reading. In fact, in the past, it was taken for granted that all the professions related to language were actually men's profession. For this long-standing male dominance, English, like many other languages, became, in some quite general sense, a male language (Penelope, 1990; Spender, 1985) - it now encodes a male worldview, subordinates women and renders them invisible, and takes males as norm. On this premise, anyone can presume that male students can definitely learn English as a second language better than the female students. Surprisingly, most of the recent relevant studies got opposite findings (Richard \& Lesley, 2007; Halpern, 1986; Yang, 2001; Kimura, 2006, as cited in Piasecka, 2010, pp. 146-149; RÚA, 2006, p. 110). However, no such study has been conducted in Bangladesh. Although public examination results show that young female students are increasingly doing better at secondary and higher secondary levels, without analyzing their answer scripts it is very difficult to draw any conclusion regarding learning English as a second language only on the basis of total marks .

Syed Md Golam Faruk, professor, Ph.D., Director, Directorate of Secondary and Higher Education, Chittagong, Bangladesh. Rajib Saha, lecturer, M.A., English Department, Chittagong City Corporation Premier College, Chittagong, Bangladesh. 
In this backdrop of these projected disparities between historical facts and theories implying man's superiority over woman on the one hand, and recent study findings showing girls as better language learners than the boys on the other, we tried to do a comparative study between Bangladeshi higher secondary level female and male students. In order to avoid research effect, the study was integrated with higher secondary curriculum. In other words, students' data were collected from their regular exams and school records (this type of school is known as "college" in Bangladesh). We compared the sexes with the following research questions:

(1) Are the female students better than male students in overall English language learning?

(2) Are the female students better than male students in English language learning where memorization is concerned?

(3) Are the female students better than male students in English language learning where grammar skill is concerned?

\section{Literature Review}

A number of studies have been conducted in order to find out the differences between male and female students in case of language learning. In this study, we will concentrate on gender differences with respect to learning English as a second language. Previous studies show the differences in three ways - in some cases males and females are simply different from each other, in a very few cases males do better than females, and in most of the cases it is just the opposite-females do better than males.

While adopting Language Learning Strategies (LLS) males and females show distinctively different characteristics. Males prefer to use linguistic devices such as interruptions, directives, and sentence initial conjunctions. On the other hand, females prefer to rely more on questions, justifiers, intensive adverbs and personal pronouns (Aries, 1967; Mulac et al., 1998; Taps \& Yancy-Martin, 1998, as cited in Gascoigne, 2002, p. 83). Holmes (2001) suggests that women in their speech prefer to use lexical hedges or fillers, tag questions, rising intonation on declaratives, empty adjectives, precise color terms, intensifiers such as just and so, hyper correct grammar, super polite forms, avoidance of strong swear words and emphatic stress. It is difficult to say whether the differences between males and females are due to biological, psychological, and socio-cultural influences or not. However, Holmes (2001) asserts that there are at least psychological and socio-cultural influences. In a similar vein, Nyikos (1990) mentions that female students seek more social approval than male students (as cited in Aslan, 2009, p. 55) and this perhaps is the reason why, what Shenadeh (1999, p. 258) observes, women tend to attain a greater amount of comprehensible input from the conversation whereas men use the conversation to get a greater amount of comprehensible output.

Oxford and Nyikos (1989) show that women use memory, cognitive and social strategies more than men and women tend to use all types of strategies more frequently. Males prefer to use reasoning capacity and catching main idea is his favorite cognitive behavior (Lin, 2011, p. 300). In another study, Bacon (1992) finds that when listening authentic second language texts, women use more metacognitive strategies than men, whereas men use greater proportion of translation strategies.

Males and females show different types of aptitude in writing. Researches show that females are better at descriptive writing and males are better at opinion writing (Richard \& Lesley, 2007). Richard and Lesley divided the students in two groups for male and female and asked them to write one descriptive and one opinion paragraph about the given topic to determine their language proficiency at pretest stage. Later the participants were given four topics for writing - two topics for descriptive writing and two for opinion writing. 
Similarly, Kimura (2006, as cited in Piasecka, 2010, pp. 146-149) finds that in at least two sub skills of writing - grammar and spelling - females are better than males. Females are better in reading, too. Halpern (1986) finds that female students tend to be more capable readers in comparison to male students.

Only in a few areas where the sexes are comparable, males do better than females. Males are better in the cognitive abilities like reasoning and analysis (Yang, 2001), and like other aspects of life, they can control and dominate conversations (Gass \& Varonis, 1986). However, in one cognitive ability, memorization, females are clearly better than males (Yang, 2001). Probably, this is the reason why the girls start learning the first language before the boys. Studies show that females learn first language better than males in their early years (Larsen-Freeman, 2000). Substantiating the folk belief, HU (1989, p. 199) finds that girls learn to speak earlier than boys and in addition to that if the whole language learning process is considered, females learn a foreign language faster and better than their male counterparts. In addition to listening and speaking, females perform better in reading and writing (Powell, 1979). However, Dale (1976) contradicts Larsen-Freeman (2000) when he observes that in pre-school and early school years, there are no differences or insignificant differences between boys and girls concerning language learning but he asserts that around the age of 10, girls develop superior verbal skills which continue through their school and college years (Dale, 1976, p. 311). In a similar vein, Kimura (2006) observes that girls' speeches are more polite, more redundant, more formal, and more clearly pronounced (Kimura, 2006, as cited in Piasecka, 2010, pp. 146-149).

In one study it was found that females' vocabulary is richer than males' (Kimura, 2006, as cited in Piasecka, 2010, pp. 146-149) and in other studies it was found that their preferred ways of vocabulary learning are also different from each other. Catalán's (2003) research on vocabulary learning shows that males prefer visual and tactile learning while females prefer auditory learning. He also observes that females prefer formal rule, input elicitation, rehearsal and planning strategies while males prefer image vocabulary learning. Researches show that in video text vocabulary learning, females excel males in the task of comprehending the content, acquiring vocabulary immediately after video viewing and retaining vocabulary after one week (Lin, 2011, p. 297). It is to be noted that when viewing a difficult video text, the performances of both genders are almost even but concerning easy video text, females are clearly ahead of males. With easy texts, females tend to remember details whereas concerning difficult text the attentive skill does not help female to comprehend the text properly (Lin, 2011, p. 298).

The findings of the above mentioned studies clearly show females' superiority to males' in language learning. Some other studies explain the reasons behind these differences between males and females. First of all, females are found to be more motivated than males. Researchers observe that females possess more positive attitude and they are more motivated than males in case of EFL learning (Dörnyei \& Clément, 2001). Dörnyei and Clément conducted a huge survey on Hungarian students' (2,377 boys and 2,300 girls aged 13-14) attitude and motivation with respect to five foreign languages (English, German, French, Italian, and Russian) in 2001. Burstall (1975) also observes that girls show more positive attitudes than boys while learning a language. He conducted a longitudinal study on the overall performances of British eight year old students of French. It was found that females were more interested than males in case of foreign language learning and their enthusiasm about the culture, country, and the speakers of the target language were higher than males. Girls show integrative motivation whereas boys' motivation is instrumental in nature (Powell \& Littlewood, 1983, p. 36). It is thought that integrative motivation promotes better language learning than instrumental motivation. In fact, 
in case of language learning integrative motivation is a stronger predicator of achievement than instrumental motivation (Krashen, 1988, p. 26). Moreover, it is commonly believed that integrative motivation helps to develop native like pronunciation and semantic system in L2 (Spolsky, 1990, p. 51).

Secondly, girls show more confidence during language learning and they have more self-esteem than boys (Powell \& Batters, 1985) which are crucial to successful language learning. Concerning language learning and self-confidence, Dulay, Burt, and Krashen (1982, p. 75) mention that self confidence helps better language learning. Krashen (1988) asserts that "self confident person or secure person will be more able to encourage intake and will also have a lower filter" (p. 23). In fact, self confidence lowers anxiety and fosters better language learning. Thirdly, researchers find that females use language learning strategies more frequently than males, particularly social strategies (Oxford, 1995; Politzer, 1983). Politzer (1983) conducted research on 90 undergraduate foreign language learners enrolled in French, Spanish, and German courses in the US and found that female learners used more social strategies than males. However, outside the classroom, in natural situations, the picture is different. A few studies conducted in that context show that males use more strategies than females while learning a target language. Tran's (1988) research shows that in the US, Vietnamese male immigrants use more LLS than females. He observes that employment situation is the reason behind it. Wharton (2000) shows that Singaporean EFL male learners use more LLS than females while learning Japanese and French.

Fourthly, it is found that girls' superior verbal intelligence helps them in better language acquisition (RÚA, 2006, p. 110). Fifthly, Liang (2001) asserts that effective integration of spatial skills and linguistic cognition help females' better language acquisition at early stage. Sixthly, girls' high aptitudes generate positive attitudes and help increase self-confidence that contributes to better achievement in EFL (RÚA, 2006, p. 110). Seventhly, females find more interest in social activities than males and they are less competitive and more co-operative (Maccoby \& Jacklin, 1974) which help better language learning. And finally, the jobs that females prefer demand better language proficiency than the jobs males usually like. Lubbers and Menting (1987) and Francis (2000) point out that society and education impose same stereotype of activities which encourage females in language learning. Francis asserts that females and males still look for different kinds of job. Girls opt for artistic or "caring" professions, and boys opting for occupations that are scientific, technical, or business oriented (Francis, 2000, p. 90).

\section{Methods}

\section{Participants}

The participants of this study were 123 higher secondary students, aged 16-18, of Chittagong City Corporation Premier College, Chittagong, Bangladesh. Among them 43 students were female and 80 were male students. As the college is situated in a suburban area, the students come from both the nearby villages and Chittagong City. Most of them are from lower middle class families. It is to be noted here that regarding family background female students are in a better position than the males. On average, the girls' families are more solvent, cultured, and educated than the boys'. Girls are also better in terms of their results in the previous Secondary School Certificate Examination. In the previous exam, girls' average GPA is 3.90 (English 4) while boys' GPA is 3.73 (English 3.75). Girls and boys are also different in some other significant ways-according to the teachers, girls are more regular, attentive, and sincere than the boys in the classes. 


\section{Material}

The materials of this study are the 123 participants' 468 answer scripts for the 1st Terminal, 2nd Terminal, 1st Year Final examination and Pre-test (the examination that is held before Final exam followed by Test examination) examinations held in the academic year 2014-2015. The question papers of 1st Terminal, 2nd Terminal, and 1st Year Final examinations have three parts: Reading Comprehension-40 marks, Vocabulary-20 marks, and Guided Writing-40 marks. Reading Comprehension is tested through Multiple Choice Questions, True/False, Fill in the Gaps, Information Transfer, Question/Answer, Summarizing and Flow Chart. For Vocabulary, the single test item is Cloze Test. Guided Writing includes Matching Phrases, Rearranging Jumbled Sentences, and Paragraph Writing answering five given questions. Pre-test examination has two parts: Grammar-60 marks and Composition-40 marks. We could not use the data from Composition as very few students answered the questions. The data were collected only from Grammar part which includes the use of article, preposition, phrases, clauses, right form of verbs, modifiers, connectors, punctuation, transformation of sentences, narration, pronoun references, and writing sentences using antonym and synonym of the given words.

Traditionally, in Bangladesh, the exam questions measure the students' "remembering" and "understanding"- the two lowest thinking skills of Revised Bloom's taxonomy (Anderson, 2001) where the hierarchy of the thinking skills from the lowest to the highest is the following: Remember, Understand, Apply, Analyze, Evaluate, and Create. As most of the students attempted the questions from Vocabulary (1st Year Final), Grammar (Pre-test), and Writing (1st Year Final), we focused mainly on these areas. The Grammar questions mostly tested the students" "understanding", the Vocabulary questions measured both their "understanding" and "remembering", and Writing questions tested only "remembering" as knowing the narrow range of probable topics to be given in the question paper, the students usually memorize the ready-made answers from "guidebooks" or "notebooks".

Besides, we also compared the female and male students on the basis of their overall performance on the 1st Terminal, 2nd Terminal, and 1st Year Final examinations. As it is mentioned above, the three examinations follow the same question pattern and each of them tests mostly the students" "understanding" through Reading Comprehension (40 marks) and a part of Guided Writing (26 marks). The students" "remembering" skill is measured through paragraph writing (14 marks) - another part of Guided Writing as the students usually memorize them. In order to answer Vocabulary (20 marks) questions, the participants need both "remembering" and "understanding" skills. Therefore, through the material of this study, we can know only female and male students' capacity of "remembering" and "understanding" and the difference between the sexes only in these two particular areas.

\section{Procedure}

We collected data for Vocabulary, Writing, and Grammar. The data for Vocabulary (20 marks) and Writing (14 marks) were taken from $1^{\text {st }}$ Year Final exam, and the data for Grammar (10 marks) were taken from the Pre-test exam. The data for all items (100 marks) were taken from three exams-1st Terminal, 2nd Terminal, and 1st Year Final examinations. Each of these exams was for 100 marks. First of all we collected the students' raw data and then calculated these mean scores out of 100 marks. It is to be noted here that we could not take all of the students as participants, because all of them did not take all the exams and all the students did not write the answers to all the questions. Therefore, we could select only 123 students who took 
all the three exams - 1st Terminal, 2nd Terminal, and 1st Year Final examinations. Among these 123 students, all the participants did not answer the required questions related to "vocabulary" and "descriptive paragraph". There were only 36 female and 44 male students who answered both "vocabulary" and "paragraph" questions in the 1st Year Final examination. For "grammar", we analyzed 43 female and 56 male students' answers as only those students answered the required grammatical items in Pre-test examination.

\section{Result}

It is clear that the females did better than the males in all the areas tabled above but the differences between the sexes have small effect size. The least significant difference between females $(M=5.29)$ and males $(M=4.83)$ is in Grammar score where the effect size $(d=0.36)$ is the smallest and moreover, this is not statistically quite significant $(p=0.075)$. Even in Writing test where the difference between females $(M=7.08)$ and males $(M=2.36)$ is more than other areas, the effect size is still not large $(d=.713)$. Similarly, although females did better than males in the rest of the items, the effect size is small. In Vocabulary, females $(M=4.22)$ did better than males $(M=3.94)$ although the effect size is small $(d=.612)$. In the same vein although females' score $(M=41.17)$ is more than males' $(M=33.54)$, the effect size is even smaller $(d=.578)$ than the previous one.

The answers to all the questions from 1st Terminal, 2nd Terminal, and 1st Year Final examinations which reflect the participants' overall language learning proficiency also show little difference between females and males. Here female students' mean score $(M=41.17)$ is higher than the males' $(M=33.54)$ but the effect size $(d=.57)$ is small.

Table 1

Comparison in Grammar

\begin{tabular}{lllllll}
\hline Gender & $\mathrm{N}$ & Range & Minimum & Maximum & Mean & Std. Deviation \\
\hline Female & 43 & 5.50 & 3.00 & 8.50 & 5.2907 & 1.52062 \\
Male & 56 & 3.50 & 3.00 & 6.50 & 4.8393 & .96816 \\
\hline
\end{tabular}

Table 2

Comparison in Vocabulary

\begin{tabular}{lllllll}
\hline Gender & $\mathrm{N}$ & Range & Minimum & Maximum & Mean & Std. Deviation \\
\hline Female & 36 & 16 & 2 & 18 & 11.00 & 4.22 \\
Male & 44 & 18 & 1 & 19 & 8.50 & 3.94 \\
\hline
\end{tabular}

Table 3

Comparison in Writing

\begin{tabular}{lllllll}
\hline Gender & $\mathrm{N}$ & Range & Minimum & Maximum & Mean & Std. Deviation \\
\hline Female & 36 & 8 & 2 & 10 & 7.08 & 2.36 \\
Male & 44 & 8 & 1 & 9 & 2.36 & 2.46 \\
\hline
\end{tabular}

Table 4

Student's Mean Scores of Three English Exams

\begin{tabular}{lllllll}
\hline Gender & $\mathrm{N}$ & Range & Minimum & Maximum & Mean & Std. Deviation \\
\hline Female & 43 & 57.78 & 20.28 & 78.06 & 41.1789 & 14.10667 \\
Male & 80 & 65.55 & 9.45 & 75.00 & 33.5454 & 12.19747 \\
\hline
\end{tabular}


Table 5

Comparison Between Females and Males in All the Tests

\begin{tabular}{llllll}
\hline Condition & Area & Total marks & Mean difference & $P$ & Cohen's $d$ \\
\hline \multirow{5}{*}{ Female vs. Male } & Grammar & 10 & 0.45 & 0.075 & 0.361 \\
& Vocabulary & 20 & 2.50 & 0.007 & 0.612 \\
& Writing & 15 & 1.72 & 0.002 & 0.713 \\
& $\begin{array}{l}\text { Student's Mean } \\
\text { Scores in Three }\end{array}$ & 100 & 7.63 & 0.002 & 0.578 \\
\hline
\end{tabular}

\section{Discussion}

The results presented above show that females are not essentially better than males in English language learning. Although in all the tests the females' mean score is higher than the males', for the small effect size of the difference between the mean scores, we cannot conclusively say that they are better English language learners. One other observation of their class teachers is that the female students are better than males in memorization which corroborates Martínez (1994) and Yang (2001). Therefore, the area where memorization helps like Writing, the difference between the mean scores is the biggest and the area where memorization is of little help like Grammar, the difference between the mean scores is the smallest.

Therefore, females' better performance is due mainly to their memorizing capability. Two other reasons can be taken into consideration. One is their better track record in secondary education. Their average GPA is 3.90 while male students' average GPA is 3.73 . The other reason is their family background. At higher secondary level, the female students usually come from more solvent, cultured, and educated families.

\section{Conclusion}

The following conclusion, with regard to three research questions, with some caveats described below, can be drawn from this study. In all the three research areas - Grammar, Vocabulary, and Writing - female students did better than the male students but it is also to be noted here that the effect size in all the cases is small. Among these three areas, the effect size is the smallest in Grammar and the biggest in Writing. It means in answering to the Grammar questions where Bloom's "understanding" helps, females and males are almost equal and in Writing where for traditional question pattern the students depend mostly on memorization, we get the biggest mean difference with the biggest effect size. The effect size of the mean difference in Vocabulary is in between Grammar and Writing perhaps because students need both "understanding" and "remembering" in order to answer the cloze test questions. Therefore, it can be argued that there is a positive correlation between female students' tendency/capacity of memorization on the one hand and mean difference and effect size on the other.

The findings show that though the female students did better than male students in all the study areas, small effect size proves that there is no essential difference between them in terms of English language learning. The little difference with small effect size can be explained by the female students' attentiveness and sincerity in class, their performance in the previous public exam, their family backgrounds, and above all their tendency/capacity of memorization.

The study is not without limitation. The statistical findings would be more generalizable if the study were conducted with more participants. Moreover, the tests were designed only on the basis of the two lowest 
domains of Bloom's Taxonomy- "remembering" and "understanding". Therefore, the female and male students are not compared here in terms of "apply", "analyze", and "evaluate".

Nevertheless, despite these limitations, the results of this study have important pedagogical implications. They show that teachers, at least Bangladeshi EFL teachers, have to neither consider the traditional idea about males' superiority over females nor take the increasingly popular belief or recent study findings regarding girls' greater capacity of language learning for granted. If other factors remain the same, female and male students can develop equal proficiency at least in English, if not in any other second language.

\section{References}

Anderson, L. W., Krathwohl, D. R., \& Bloom, B. S. (2001). A taxonomy for learning, teaching, and assessing a revision of Bloom's taxonomy of educational objectives. New York: Longman.

Aries, E. (1967). Interaction patterns and themes of male, female, and mixed groups. Small Group Behavior, 7-18.

Aslan, O. (2009). The role of gender and language learning strategies in learning English (Master's dissertation). Retrieved from http:// etd.lib.metu.edu.tr /upload/ 12611098/index.pdf

Bacon, S. M. (1992). The relationship between gender, comprehension, processing strategies, cognitive, and affective response in foreign language listening. The Modern Language Journal, 76(2), 160-178.

Burstall, C. (1975). Factors affecting foreign-language learning: A consideration of some relevant research findings. Language Teaching and Linguistic Abstract, 8, 5-125.

Catalán, R. M. J. (2003). Sex differences in L2 vocabulary learning strategies. International Journal of Applied Linguistics, 13(1), 54-77.

Dale, P. (1976). Language development: Structure and function. New York: Holt, Rinehart and Winston.

Dörnyei, Z., \& Clément, R. (2001). Motivational characteristics of learning different target languages: Results of a nationwide survey. In Z. Dörnyei and R. Schmidt (Eds.), Motivation and second language acquisition (pp. 399-432). Hawai'i: Second Language Teaching and Curriculum Center.

Dulay, H., Burt, M., \& Krashen, S. (1982). Language two. Oxford: Oxford University Press.

Francis, B. (2000). Boys, girls and achievement: Addressing the classroom issue. London: Routledge.

Gascoigne, C. (2002). The role of gender in L2 interaction: Socialization via L2 materials. Encuentro Revista de investigación e innovación en la clase de idiomas, 13-14, 81-89.

Gass, S., \& Varonis, E. (1986). Sex differences in non-native speaker interactions. In R. Day (Ed.), Talking to learn: Conversation in second language acquisition (pp. 327-351). Rowley, MA: Newbury House.

Halpern, D. F. (1986). Sex differences in cognitive abilities. Cambridge: Cambridge University Press.

Holmes, J. (2001). An introduction to sociolinguistics (2nd ed.). Harlow, England: Pearson Education.

Hu, Z. (1989). Linguistics: An introduction. Peking : Peking University Press.

Krashen, S. (1988). Second language acquisition and second language learning. Englewood Cliffs, N.J.: Prentice Hall.

Larsen-Freeman, D., \& Long. M. H. (2000). An introduction to second language acquisition research. Beijing: Foreign Language Teaching and Research Press.

Liang, X. (2001). The neurolinguistic significance of gender differences to the establishment of optimized SLA strategies. Foreign Languages and Their Teaching, 6.

Lin, L. F. (2011). Gender differences in L2 comprehension and vocabulary learning in the video-based CALL program. Journal of Language Teaching and Research, 2(2), 295-301. doi:10.4304

Lubbers, J., \& Menting, C. (1987). Girls and science education: Selection in classroom interaction. In D. Brouwer and D. de Haan (Eds.), Women's language, socialization and self-image (pp.114-126). Dordretch: Foris Publications.

Maccoby, E. E., \& Jacklin, C. N. (1974). The psychology of sex differences. Stanford: Stanford University Press.

Mulac, A., Wieman, J., Widenmann, S., \& Gibson, T. (1998). Male/Female language differences and effects in same-sex and mixed-sex dyads: The gender-linked language effect. Communication Monographs, 315-335.

Oxford, R. (1995). Gender differences in language learning styles: What do they mean? In J. M. Reid (Ed.), Learning styles in the ESL/EFL classroom. New York: Heinle and Heinle.

Oxford, R., \& Nyikos, M. (1989). Variables affecting choice of language learning strategies by university students. Modern Language Journal, 73, 291-300. 
Penelope, J. (1990). Speaking freely: Unlearning the lies of the fathers' tongues. NY: Pergamon.

Piasecka, L. (2010). Gender differences in L1 and L2 reading. In J. Arabski and A. Wojtaszek (Eds.), Neurolinguistic and psycholinguistic perspectives on SLA (pp. 145-158). Toronto: Multilingual Matters.

Politzer, R. L. (1983). An exploratory study of self reported language learning behaviors and their relation to achievement. Studies in Second Language Acquisition, 6, 54-68.

Powell, R. C. (1979). Sex differences in language learning: A review of the evidence. Audio-Visual Language Journal, 17(1), 19-24.

Powell, R. C., \& Batters, J. D. (1985). Pupils perceptions of foreign language learning at 12+: Some gender differences. Educational Studies, 11(1), 12-23.

Powell, R. C., \& Littlewood, P. (1983). Why choose French? Boys' and girls' attitudes at the option stage. The British Journal of Language Teaching, 21(1), 36-40.

Richard, J. C., \& Lesley, T. (2007). Interlanguage language placement test. Cambridge: Cambridge University Press.

RÚA, P. L. (2006). The sex variable in foreign language learning: An integrative approach. Porta Linguarum, 6, 99-144.

Shenadeh, A. (1999). Gender differences and equal opportunities in the ESL classroom. ELT Journal, 53(4), $256-261$.

Spender, D. (1985). Man made language (2nd ed.). New York: Routledge.

Spolsky, B. (1990). Conditions for second language learning. Oxford: Oxford University Press.

Tran, T. V. (1988). Gender differences in English language acculturation and learning strategies among Vietnamese adults aged 40 and over in the United States. Gender Roles, 19, 747-758.

Wharton, G. (2000). Language learning strategy use of bilingual foreign language learners in Singapore. Language Learning, 50, 203-243.

Yang, Y. L. (2001). Sex and language proficiency level in color-naming performance: An ESL/EFL perspective. International Journal of Applied Linguistics, 11(2), 238-256. 